$\ll$ Research Note $\gg$

\title{
Genetic Differentiation and Phylogenetic Relationships among Species of Gallus (Jungle Fowl) and the Chicken
}

\author{
Noriko Ohta $^{1,2}$, Manabu KaJita ${ }^{2}$, Seiji Kusuhara ${ }^{1}$ and Ryozo Kakizawa ${ }^{2}$ \\ ${ }^{1}$ Graduate School of Science and Technology, Niigata University, Niigata 950-2181 \\ ${ }^{2}$ Yamashina Institute for Ornithology, Abiko, Chiba 270-1145
}

By means of protein electrophoresis on 32 loci (22 enzymes), genetic variation and differentiation among 20 individual birds of 4 species of Gallus (Gallus gallus, G. lafayettei, G. sonneratii and G. varius), and the chicken were analyzed. A genealogic dendrogram was constructed by the UPGMA method, using the genetic distances among species. In the present study, G. gallus and the chicken were shown to have genetic distance at the subspecies level, and genetic distance gradually increasing with the G. sonneratii, $G$. lafayettei and $G$. varius.

(Jpn. Poult. Sci., 37 : 33-39, 2000)

Key words : Gallus, Jungle Fowl, Chicken, phylogeny, isozyme

\section{Introduction}

The genus Gallus (subfamily Phasianinae, the family Phasianidae, the order Galliformes) consists of 4 species ; Red Jungle Fowl (Gallus gallus), Ceylon Jungle Fowl (G. lafayettei), Grey Jungle Fowl (G. sonneratii) and Green Jungle Fowl (G. varius), (Peters, 1976). Gallus members live on the ground and are distributed in India, southern China and Southeast Asia, and are characterized by sexual dimorphism. Some studies have investigated the relationships among the 4 species of Gallus by protein electrophoresis of blood samples (HASHIGUCH et al. 1981, 1986, ОкаDA et al. 1984), but the results vary except for their demonstration that G. varius is distantly related to other Gallus members.

Chickens have long been domesticated, and are very important to human subsistence, and are sometimes kept for amusement. Since it is generally believed that the chicken originates from the Red Jungle Fowl (G. gallus), we studied its relationship to the Gallus species.

In the present study, the relationships among Gallus members and the chicken were examined by electrophoretic analysis on 32 loci (22 enzymes) with tissues (liver, muscle and heart) taken from the four Gallus species and the chicken.

\footnotetext{
Received August 9, 1999 Accepted September 30, 1999

アイソザイムによるヤケイ属鳥類の類縁関係

太田紀子 ${ }^{1,2} \cdot$ 梶田 学 $^{2} \cdot$ 楠原征治 1 柿沢亮三 ${ }^{2}$

1. 新潟大学大学院自然科学研究科, 新潟市 950-2181

2. (財)山階鳥類研究所, 我孫子市 270-1145

キーワード : ヤケイ属, ニワトリ, 類縁関係, アイソザイム
} 


\section{Materials and Methods}

G. gallus $(\mathrm{n}=7)$, G. lafayettei $(\mathrm{n}=3), G$. sonneratii $(\mathrm{n}=1), G$. varius $(\mathrm{n}=4)$ and the chicken $(n=5)$ were collected between August 1993 and June 1996. Specimens were obtained from the Tokyo Tama Zoological Park, the Dusit Zoo in Thailand, bird markets in Bali, Indonesia and individual dealers in Japan and abroad. Birds were preserved at $-80^{\circ} \mathrm{C}$. Each bird was defrosted to remove samples of liver, muscle and heart, which were minced for experimental use and preserved at $-80^{\circ} \mathrm{C}$. Livers, muscles and hearts dissected from the birds were homogenized, and then centrifuged at $15,000 \times \mathrm{g}$ for 20 minutes at $2^{\circ} \mathrm{C}$. After centrifugation the supernatant was divided into aliquots and stored in capillary glass tubes at $-80^{\circ} \mathrm{C}$ until electrophoresis. Extracts of liver, muscle and heart were subjected to starch gel electrophoresis to determine the allelic composition for each protein locus. The combinations of tissues and buffer systems for enzyme detection are shown in Table 1. The staining methods for enzymes were essentially the same as those described by Bell et al. (1982), SHAw and Prasad (1970), Selander et al. (1971), Hopkinson et al. (1973), Harris and Hopkinson (1976), and NumAchi et al. (1979). These enzymes and proteins are assumed to be coded by the 32 gene loci.

Genetic identities and genetic distances between species were calculated using

Table 1. Combinations of tissues and buffer systems for the detection of enzymes.

\begin{tabular}{llll}
\hline \multicolumn{1}{c}{ Protein } & Abbr. & \multicolumn{1}{c}{ Tissues } & Buffers* \\
\hline Alcohol dehydrogenase & ADH & Liver & Tris-citrate \\
Creatine kinase & CK & Muscle, Heart & Tris-citrate \\
Esterase-D & ESD & Liver & Tris-citrate \\
Esterase & EST & Liver & Tris-HCl \\
Glutamate dehydrogenase & GDH & Liver & Tris-citrate \\
Glutamate oxaloacetate transaminase & GOT & Liver & Tris-citrate \\
Glutamate 6-phosphate dehydrogenase & G6PDH & Liver & Tris-citrate \\
$\alpha$-Glycerophosphate dehydrogenase & $\alpha-$ GPDH & Muscle & Tris-citrate \\
Glucosephosphate isomerase & GPI & Muscle & Tris-citrate \\
Isocitrate dehydrogenase & IDH & Liver & Tris-citrate \\
Lactate dehydrogenase & LDH & Muscle, Heart & Tris-citrate \\
Malate dehydrogenase & MDH & Liver & Tris-citrate \\
Malic enzyme & ME & Liver & Tris-citrate \\
Mannosephosphate isomerase & MPI & Heart & Tris-citrate \\
Peptidase & PEP & Liver & Tris-citrate \\
6-Phosphogluconate dehydrogenase & $6 P G D$ & Liver & Tris-citrate \\
Phosphoglucomutase & PGM & Liver & Tris-citrate \\
General protein & PT & Muscle & Tris-citrate \\
Sorbitol dehydrogenase & SDH & Liver & Tris-citrate \\
Superoxide dismutase & SOD & Liver & Tris-citrate \\
Xanthine dehydrogenase & XDH & Liver & Tris-citrate \\
Xylulose reductase & XR & Liver & Tris-citrate \\
\hline
\end{tabular}

*Tris-HCl : Selander et al. (1971), Tris-citrate : Numachi et al. (1983). 
NEI's (1972) formula, and the values of genetic distances were clustered into a dendrogram using the unweighted pair-group method of analysis with arithmetic means (UPGMA) (SNEATH and SoKAL, 1973).

\section{Results}

\section{(1) Genetic variation}

Alleles detected at each locus which showed the variations, and the frequency of allele occurrence are shown in Table 2. The number of birds in each species ranged from one to seven, and genetic variation was found between the chicken and all species of Gallus, but G. sonneratii, in which only one specimen was examined. The species with the highest genetic variation was $G$. varius (7 loci), and the species showing the second-highest genetic variation was $G$. lafayetti (6 loci). The loci which showed the variation within a species were 11 loci : EST (two species of Gallus and the chicken), ME (three species of Gallus), ESD-1, PEP-1, PEP-2 (two species of Gallus), ADH-2 (one species of Gallus and the chicken), IDH-2, MPI, PT-3, SDH (one species of Gallus) and GOT-1 (the chicken). The largest number of alleles found at any one locus was three, found at $\mathrm{ADH}-2$, EST and PEP-2.

Of the 32 loci tested, inter-specific variations were found in 13 loci (ADH-2, CK-2, ESD-1, EST, GOT-1, IDH-2, ME, MPI, PEP-1, PEP-2, PT-2, PT-3 and SDH). Nineteen loci (ADH-1, CK-1, ESD-2, GDH, GOT-2, G 6 PDH, $\alpha$-GPDH, GPI, IDH-1, LDH-1, LDH-2, MDH-1, MDH-2, 6 PGD, PGM, PT-1, SOD, XDH and XR) were limited to single alleles and are therefore monotypic. $\mathrm{CK}^{-2}$ and $\mathrm{PT}-2$ showed a single allele except for $G$. varius.

(2) Genetic differentiation

Genetic identity and distance were calculated from the data given in Table 3 according to Nels (1972) formula. The results obtained from the analysis of the 32 loci showed that none of the species had the same genetic structure, therefore there is genetic variation among all Gallus members and the chicken. Within the Gallus group, the lowest genetic differentiation was shown between G. gallus and G. sonneratii (0.0619), and the highest genetic differentiation was shown between $G$. sonneratii and $G$. varius (0.1364). The mean genetic distance for the 4 species of Gallus was 0.092 , which is almost the same as the currently documented mean genetic distance for NonPasseriformes (Kuroda et al. 1990, Barrowclough et al. 1981, Numachi et al. 1983 and WATADA et al. 1987). The extremely low genetic differentiation between the chicken and $G$. gallus was reflected by a genetic distance of only 0.0073 . The highest value (0.1153) of genetic distance in the chicken was found between G. varius.

(3) Genetic relationships within Gallus

By means of the UPGMA procedure, a genealogic dendrogram (Fig. 1) was constructed, based on values for inter-specific distances within Gallus. The dendrogram shows that the chicken is most closely related to G. gallus. In descending order of distance, next comes $G$. sonneratii, G. lafayettei and finally, the most distantly related $G$. varius. However the placement of $G$. sonneratii was not confirmed since only one individual specimen was available for this study. Even if the G. sonneratii is dis- 
Table 2. Alleles and their frequencies from the loci which

\begin{tabular}{|c|c|c|c|c|c|c|c|}
\hline & Species & $\mathrm{ADH}-2$ & $\mathrm{CK}-2$ & $\mathrm{ESD}-1$ & EST & GOT-1 & IDH-2 \\
\hline 1) & Gallus gallus & $\begin{array}{l}\mathrm{b}=0.857 \\
\mathrm{c}=0.143\end{array}$ & a & $\mathrm{a}$ & $\mathrm{b}$ & $\mathrm{b}$ & a \\
\hline 2) & Gallus lafayettei & $\mathrm{b}$ & $\mathrm{a}$ & $\begin{array}{l}a=0.333 \\
b=0.667\end{array}$ & $\begin{array}{l}b=0.667 \\
c=0.333\end{array}$ & $\mathrm{~b}$ & $\mathrm{a}$ \\
\hline 3) & Gallus sonneratii & $\mathrm{a}$ & $\mathrm{a}$ & $\mathrm{a}$ & $\mathrm{b}$ & $\mathrm{b}$ & $\mathrm{a}$ \\
\hline 4) & Gallus varius & $\mathrm{b}$ & $\mathrm{b}$ & $\begin{array}{l}a=0.750 \\
b=0.250\end{array}$ & $\begin{array}{l}\mathrm{b}=0.750 \\
\mathrm{c}=0.250\end{array}$ & $\mathrm{~b}$ & $\begin{array}{l}\mathrm{a}=0.750 \\
\mathrm{~b}=0.250\end{array}$ \\
\hline 5) & Chicken & $\begin{array}{l}\mathrm{a}=0.200 \\
\mathrm{~b}=0.800\end{array}$ & $\mathrm{a}$ & $\mathrm{a}$ & $\begin{array}{l}a=0.400 \\
b=0.600\end{array}$ & $\begin{array}{l}a=0.100 \\
b=0.900\end{array}$ & $\mathrm{a}$ \\
\hline
\end{tabular}

Table 3. Matrix of genetic identity (above diagonal) and genetic distance (below diagonal) between species of Gallus.

\begin{tabular}{lccccc}
\hline \hline & G. gallus & G. lafayetii & G. sonneratii & G. varius & Chicken \\
\hline Gallus gallus & - & 0.9363 & 0.9400 & 0.8964 & 0.9927 \\
G. lafayettei & 0.0659 & - & 0.9248 & 0.9056 & 0.9315 \\
G. sonneratii & 0.0619 & 0.0782 & - & 0.8725 & 0.9427 \\
G. varius & 0.1094 & 0.0992 & 0.1364 & - & 0.8911 \\
Chicken & 0.0073 & 0.0709 & 0.0590 & 0.1153 & - \\
\hline
\end{tabular}

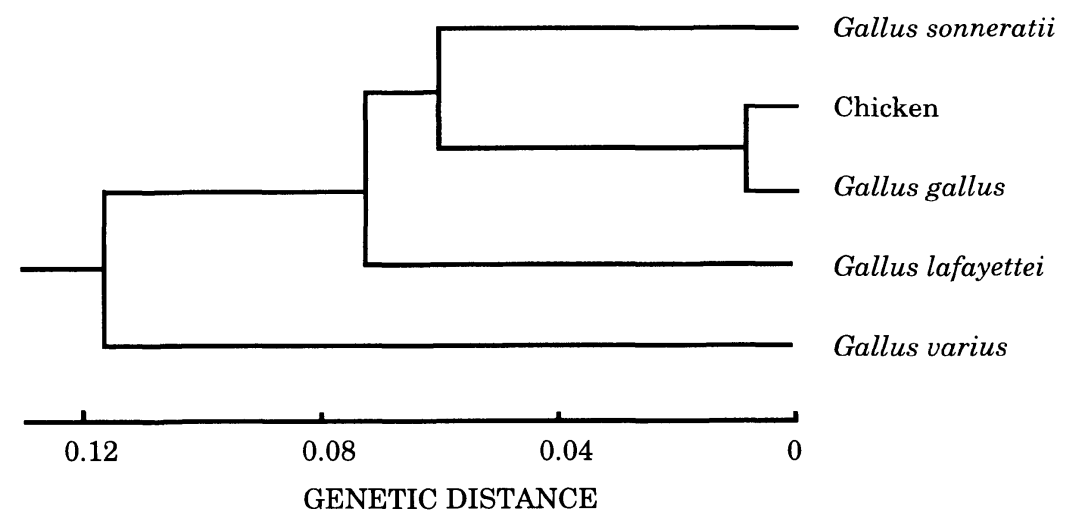

Fig. 1. Dendrogram of genus Gallus based on 32 loci, generated according to the UPGMA method.

counted, the order of the relation among the other four species is unchanged.

\section{Discussions}

(1) Genetic variation and differentiation of Gallus

Morphological studies have shown that the males of each species have strong phenotypic characteristics. G. gallus, G. soneretti and G. lafayettei all have a notched crown, two wattles and 14 tail feathers, but $G$. varius has a smooth crown, a large single 
showed the variations. Alleles are shown as a, b and $\mathrm{c}$.

\begin{tabular}{ccccccc}
\hline \hline ME & MPI & PEP-1 & PEP-2 & PT -2 & PT-3 & SDH \\
\hline $\mathrm{a}=0.143$ & $\mathrm{a}$ & $\mathrm{b}$ & $\mathrm{b}$ & $\mathrm{a}$ & $\mathrm{b}$ & $\mathrm{a}=0.929$ \\
$\mathrm{~b}=0.857$ & $\mathrm{a}$ & $\mathrm{a}=0.667$ & $\mathrm{a}=0.667$ & $\mathrm{a}$ & $\mathrm{a}=0.333$ & $\mathrm{~b}=0.071$ \\
$\mathrm{a}=0.333$ & $\mathrm{~b}=0.333$ & $\mathrm{c}=0.333$ & & $\mathrm{~b}=0.667$ & $\mathrm{a}$ \\
$\mathrm{b}=0.667$ & $\mathrm{a}$ & $\mathrm{b}$ & $\mathrm{a}$ & $\mathrm{a}$ & $\mathrm{b}$ & $\mathrm{a}$ \\
$\mathrm{b}$ & $\mathrm{a}=0.750$ & $\mathrm{a}=0.250$ & $\mathrm{a}=0.250$ & $\mathrm{~b}$ & $\mathrm{~b}$ & $\mathrm{a}$ \\
$\mathrm{a}=0.250$ & $\mathrm{~b}=0.250$ & $\mathrm{~b}=0.750$ & $\mathrm{c}=0.750$ & & & $\mathrm{a}$ \\
$\mathrm{b}=0.750$ & $\mathrm{a}$ & $\mathrm{b}$ & $\mathrm{b}$ & $\mathrm{a}$ & $\mathrm{b}$ & \\
$\mathrm{b}$ & & & & & &
\end{tabular}

wattle and 16 tail feathers. As well, G. varius has a rounded fish-scale shaped neck feathers like the pheasant, but the other three species of Gallus have a long neck feathers.

Some studies have investigated the relationships among the 4 species of the Gallus by carrying out protein electrophoresis of blood samples (HASHIGUCH et al. 1981, 1986, OKADA et al. 1984), but the results vary except for the finding that G. varius is distantly related to other Gallus members, the results of these experiments were not consistent. The results of the present study on the relationship among Gallus are similar to the findings of HASHIGUCH et al. (1986). Both the morphological data and these experiments indicate that $G$. varius is distantly related to other Gallus members.

When considering the relationship between two species, it is important to determine if two species can be cross bred and if their hybrid (F 1) is fertile. GRAY (1958) reported several studies on experimental crossing among Gallus members. It shows that only the hybrid between $G$. gallus and $G$. lafayettei has fertility, indicating that these two species are closely related. Hybrids between $G$. sonneratii or $G$. varius and other Gallus members occur infrequently, and are therefore considered to be distantly related. These crossing experiments show that G. gallus and G. lafayettei are closely related to each other, in contrast to the results of our study. In our study, only one specimen of $G$. sonneratii was analyzed, thus more data is needed to discuss the phylogenetic position of $G$. sonneratii.

(2) Relationship between the chicken and 4 species of Gallus

Collias et al. (1967) studied the lives of G. gallus, G. lafayettei and G. sonneratii, and reported the similarities between $G$. gallus and the chicken regarding both breeding behavior and voice repertoires.

Morphological and biochemical reports on the native Jungle Fowl and the chicken in Southeast Asia (HAYAshi et al. 1983, Nishida et al. 1983), have shown that hybridization rarely occurs between the chicken and $G$. varius although they share the same territory. They also indicated that the chicken and G. gallus often hybridize successfully and frequently although they have distant home ranges. On the other hand, in the crossing experiments among the chicken and species of Gallus, only the chicken and $G$. gallus can be cross bred to create a hybrid with normal fertility. Cross 
breeding between G. lafayettei, G. sonneratii or G. varius and the chicken result in F 1 hybrids that produce fertilized eggs that do not hatch or that have a very low hatching rate (Gray, 1958). Also, an analysis by Akishinonomiy A, F. et al. (1996), of the sequence of the D-loop region of the mitochondrial DNA of the chicken and Gallus in Thailand and Indonesia, produced data similar to ours, showing a close relationship between the chicken and G. gallus. These studies reinforce current research indicating that the original species of the chicken is $G$. gallus.

\section{Acknowledgements}

We wish to express our deep appreciation of Dr. N. KunodA, the director of the Yamashina Institute for Ornithology, for giving us the opportunity to carry out this study. We thank the Tokyo Tama Zoological Park and the Dusit Zoo in Thailand, for providing samples.

\section{References}

Akishinonomiya, F., Miyake, T., Takada, M., Shingu, R., Endo, T., Gojobori, T., Kondo, N. and Ohno, S. (1996) Monophyletic origin and unique dispersal patterns of domestic fowls. Proceedings of the Natural Academy of Sciences of the U.S.A., 93:6792-6795.

Barrowclough, G.F., Corbin, K.W. and Zink, R.M. (1981) Genetic differentiation in the Procellariiformes. Comparative Biochemistry and Physiology, 69 B : 629-632.

Bell, L.J., Moyer, J.T. and Numachi, K. (1982) Morphological and genetic variation in Japanese populations of the Anemonefish Amphiprion clarkii. Marine Biology, 72 : 99-108.

Collias, N.E. and Collias, E.C. (1967) A field study of the Red Jungle Fowl in North-Central India. The Condor, $69:$ 360-380.

Gray, A.P.M.A. (1958) Gallus. In 'Bird Hybrids. A check-list with bibliography, Commonwealth Agricultural Bureaux' pp. 96-101. Farnham Royal, Bucks, England.

HaRRIS, H. and Hopkinson, D.A. (1976) Handbook of enzyme electrophoresis in human genetics. North-Holland Publ. Co., Amsterdam.

Hashiguchi, T., Tsuneyoshi, M., Nishida, T., Higashiuwatoko, H. and Hiraoka, E. (1981) Phylogenetic relationships determined by the blood protein types of Fowls. The Japanese journal of Zootechnical Science, 52 : 713-729. (In Japanese with English Summary).

Hashiguchi, T., Okamoto, S., Nishida, T., Hayashi, Y., Goto, H. and Cyril, H.W. (1986) Blood protein variations of the Ceylon Jungle Fowl and native fowl in Sri Lanka. Report of the Society for Researches on Native Livestock, 11 : 193-207. (In Japanese with English Summary).

Hayashi, Y., Nishida, T., Hashiguchi, T., IKeda, K. and Mansjoer., S.S. (1983) A radio-telemetry of the Red Jungle Fowl and Green Jungle Fowl in Indonesia. Report of the Society for Researches on Native Livestock, $10: 168-171$. (In Japanese).

Hopkinson, D.A., Mestriner, M.A., Cortner, J. and Harris, H. (1973) Esterase D : A new human polymorphism. Annals of Human Genetics, 37 : 119-137.

KuRODA, N., KAKIZAWA, R. and WATAdA, M. (1990) Genetic divergence and relationships in fifteen species of Procellariiformes. Journal of the Yamashina Institute for Ornithology, 22 : 114-123.

NeI, M. (1972) Genetic distance between populations. The American Naturalist, 106 : 283-292.

Nishida, T., Hayashi, Y., Hashiguchi, T. and MansJoer., S.S. (1983) Ecological and morphological studies on the Jungle Fowl in Indonesia. Report of the Society for Researches on Native Livestock, 10 : 155-167. (In Japanese).

Numachi, K., Nagahora, S. and Iwata, M. (1979) Genetic demonstration of hybrids between chum and pink salmon in the Northwest Pacific. Otsuchi Marine Research Center Report, 5 : 87-102. (In Japanese).

Numachi, K., Watada, M., Kakizawa, R. Kuroda, N. and Utida, S. (1983) Evolutionary genetics of the Anatidae. Tori, $32: 63-74$. 
Okada, I., Yamamoto, Y., Hashiguchi, T. and Ito, S. (1984) Phylogenetic studies on the Japanese native breeds of chickens. Japanese Poultry Science, 21 : 318-329.

Peters, J.L. (1976) Order Galliformes In 'Check-list of birds of the World' Vol.II, pp. 3-133. Harvard University Press, Cambridge.

Selander, R.K., Smith, M.S. YAng, S.Y., Johonson, W.E. and Gentry, J.B. (1971) Biochemical polymorphism and systematics in the genus Peromyscus. Variation in the old-field mouse (Peromyscus polynotus). Studies in Genetics, The University of Texas publication, 7103 : 49-90.

SHAW, C.R. and PRASAD, R. (1970) Starch gel electrophoresis of enzymes-A compilation of recipes. Biochemical Genetics, 4 : 297-320.

Sneath, P.H.A. and SoKal, R.R. (1973) Numerical Taxonomy. W.H. Freeman and Co., San Francisco. Watada, M., Kakizawa, R., Kuroda, N. and Utida, S. (1987) Genetic differentiation and phylogenetic relationships of an avian family, Alcidae (Auks). The Journal of the Yamashina Institute for Ornithology, $19: 79-88$. 